\title{
Research in child and adolescent psychiatry: a multi-disciplinary, many-faceted endeavor
}

\author{
Veit Roessner
}

Published online: 3 January 2014

(C) Springer-Verlag Berlin Heidelberg 2013

Recently, Sonuga-Barke [18] pondered on the spirit and purpose of editorials in child and adolescent psychiatry research. He described that editorials are typically inspired from the findings reported in a particular paper or a set of papers and their potential implications. Correspondingly, many previous editorials of European Child and Adolescent Psychiatry (ECAP) found a 'golden thread' and presented a brief survey through the published findings. But for the current issue, such a 'linking theme' does not leap to the eye probably because the authors once again report about interesting and important studies using various methodological approaches and dealing with diverse topics of child and adolescent psychiatry. This reflects the multi-disciplinary, many-faceted nature of child and adolescent psychiatry at its best.

Van Andel et al. report about the possibility to use salivary cortisol as a biomarker in evaluating stress and effects of interventions in young foster children [19]. The findings from a Danish population-based twin study on autism spectrum disorders (ASDs) support a genetic etiology of ASDs [12]. Another report from Northern Europe, based on a Finnish register-based regional study, hints that the use of firearms plays a major role in explaining the northern excess in young Finnish male suicide rates [9]. In a German clinical sample, the relationship of callous-unemotional traits with conduct problems in girls has been studied [17]. The significance of traits of ASDs in children with attention deficit hyperactivity disorder (ADHD) has been studied in a clinical sample recruited through child psychiatry and pediatric outpatient clinics in the United Kingdom [5]. And last but not least,

\section{Roessner ( $\square)$}

Department of Child and Adolescent Psychiatry, University of Dresden Medical School, Fetscherstrasse 74, 01307 Dresden, Germany

e-mail: Veit.Roessner@uniklinikum-dresden.de
Comparelli et al. [3, 4] describe in their case report the rapid conversion to psychosis of delusional misidentification associated with derealisation, verbal memory impairment and FDG-PET imaging abnormalities although assessment with both the ultra-high risk (UHR) and the basic symptoms approaches revealed no prodromal signs with imminent risk of transition to psychosis.

In his editorial, Sonuga-Barke [18] also broke a row for 'meta issues' dealing with “....aspects of the practice of a scientific discipline that affect all researchers and their studies but which are not highlighted by the findings in any one particular paper...". While mulling over an interesting 'meta issue' instead of a not so apparent 'linking theme' the heterogeneity of methods, samples, disorders, etc. in the current issue of ECAP suggested itself. Is this heterogeneity, reflecting the multi-disciplinary, many-faceted nature of child and adolescent psychiatry research, a chance or pitfall?

In relation to both the complexity of the disorders under investigation (e.g., note gene-environment interactions) and the significant changes during development available research funding, man power, etc. are limited particularly in child and adolescent psychiatry [6]. But fortunately, several multinational research projects on child and adolescent psychiatric issues funded by the EU FP7 program $[1,2,8,11,15]$ as well as the request for input of the child and adolescent psychiatry community to the upcoming research framework of the European Union called "Horizon 2020" reflect the dramatically increased interest on high quality research in the field of child and adolescent psychiatry. Nevertheless, in the last 5 years, the economic crises mainly in the EU and US jeopardizes this positive development particularly by curtailing research funding by national agencies [10]. Therefore, some may argue that focusing, e.g., on the most common or most relevant child 
and adolescent psychiatric disorders, on therapeutic issues only or on training and health service research would be the 'order of the day' to deal optimally with the increasingly strict limitations of resources. But not only 'content-related focusing' should be discussed: also methodological questions arise in view of the papers of the current ECAP issue, e.g., how large is the impact and cost-benefit ratio of the different sampling methodologies, i.e. comparing registerbased versus clinically selected versus single case studies. Additionally, it has to be considered that several articles of ECAP (e.g., [7, 14]) highlight the strengths of and need for prospective longitudinal study designs in child and adolescent psychiatry research. However, this recommendation has hardly been implemented i.a. because of the limited resources. Thus, one main question to answer is: how large is the potential of the specific study design to come to firm conclusions, to promote further research and how good is its cost-benefit ratio?

Fortunately, a prioritization of future research needs is getting more and more attention not only from decision makers but also from research science $[13,16]$. Certainly, the discussion around the prioritization process should not be leaved to single groups of health care and quality researchers or decision makers, but rather should be guided by all means by research experts of the specific field from all over the world. Therewith, the important role of transnational scientific journals such as ECAP with a multidisciplinary, many-faceted selection of papers is highlighted once again. In the end, this multifarious nature of research in child and adolescent psychiatry is a chancenot only to affect the prioritization process but also to draw attention to a lively, varied and interesting discipline.

\section{References}

1. Bolte S, Marschik PB, Falck-Ytter T, Charman T, Roeyers H, Elsabbagh M (2013) Infants at risk for autism: a European perspective on current status, challenges and opportunities. Eur Child Adolesc Psychiatry 22:341-348

2. Buitelaar JK, Smeets KC, Herpers P, Scheepers F, Glennon J, Rommelse NN (2013) Conduct disorders. Eur Child Adolesc Psychiatry 22(Suppl 1):S49-S54

3. Comparelli A, Kotzalidis GD, Di Pietro S, Casale AD, De Carolis A (2013) A case of rapid conversion to psychosis of delusional misidentification associated with derealisation, verbal memory impairment and FDG-PET imaging abnormalities. Eur Child Adolesc Psychiatry. doi:10.1007/s00787-013-0420-z

4. Comparelli A, Kotzalidis GD, Di Pietro S, Del Casale A, De Carolis A (2013) Erratum to: A case of rapid conversion to psychosis of delusional misidentification associated with derealisation, verbal memory impairment and FDG-PET imaging abnormalities. Eur Child Adolesc Psychiatry. doi:10.1007/ s00787-013-0431-9

5. Cooper M, Martin J, Langley K, Hamshere M, Thapar A (2013) Autistic traits in children with ADHD index clinical and cognitive problems. Eur Child Adolesc Psychiatry. doi:10.1007/ s00787-013-0398-6

6. Hebebrand J, Schepker R, Herpertz-Dahlmann B, Remschmidt H, Warnke A (2006) Memorandum for improving research performance and for supporting the future medical generation in child and adolescent psychiatry, psychosomatic medicine and psychotherapy. Z Kinder Jugendpsychiatr Psychother 34:169-176

7. Hoekstra PJ (2010) The need for a long-term perspective in child and adolescent psychiatry. Eur Child Adolesc Psychiatry 19:687-688

8. http://ec.europa.eu/research/health/medical-research/brain-research/ projectsfp7_en.html

9. Lahti A, Keränen S, Hakko H, Riala K, Räsänen P (2013) Northern excess in adolescent male firearm suicides: a registerbased regional study from Finland, 1972-2009. Eur Child Adolesc Psychiatry. doi:10.1007/s00787-013-0422-x

10. Leach-Kemon K, Chou DP, Schneider MT, Tardif A, Dieleman JL, Brooks BP, Hanlon M, Murray CJ (2012) The global financial crisis has led to a slowdown in growth of funding to improve health in many developing countries. Health Aff (Millwood) 31:228-235

11. Murray ML, Insuk S, Banaschewski T, Neubert AC, McCarthy S, Buitelaar JK, Coghill D, Dittmann RW, Konrad K, Panei P, Rosenthal E, Sonuga-Barke EJ, Wong IC (2013) An inventory of European data sources for the long-term safety evaluation of methylphenidate. Eur Child Adolesc Psychiatry 22:605-618

12. Nordenbæk C, Jørgensen M, Kyvik KO, Bilenberg N (2013) A Danish population-based twin study on autism spectrum disorders. Eur Child Adolesc Psychiatry. doi:10.1007/s00787-0130419-5

13. Rockville MD (2013) Agency for healthcare research and quality (US). Report No.: 12(13)-EHC152-EF. AHRQ methods for effective health care. For details see http://www.ncbi.nlm.nih. gov/pubmed/23367528

14. Roessner V (2012) European child and adolescent psychiatryendorse the importance of prospective longitudinal study designs. Eur Child Adolesc Psychiatry 21:655-656

15. Roessner V, Hoekstra PJ (2013) European Multicenter Tics in Children Studies (EMTICS): exploring the onset and course of tic disorders. Eur Child Adolesc Psychiatry 22:451-452

16. Schumann G, Binder EB, Holte A, de Kloet ER, Oedegaard KJ, Robbins TW, Walker-Tilley TR, Bitter I, Brown VJ, Buitelaar J, Ciccocioppo R, Cools R, Escera C, Fleischhacker W, Flor H, Frith CD, Heinz A, Johnsen E, Kirschbaum C, Klingberg T, Lesch KP, Lewis S, Maier W, Mann K, Martinot JL, MeyerLindenberg A, Muller CP, Muller WE, Nutt DJ, Persico A, Perugi G, Pessiglione M, Preuss UW, Roiser JP, Rossini PM, Rybakowski JK, Sandi C, Stephan KE, Undurraga J, Vieta E, van der Wee N, Wykes T, Haro JM, Wittchen HU (2013) Stratified medicine for mental disorders. Eur Neuropsychopharmacol[Epub ahead of print]. For details see http://www.ncbi.nlm.nih.gov/ pubmed/24176673

17. Schwenck C, Gensthaler A, Romanos M, Freitag CM, Schneider W, Taurines R (2013) Emotion recognition in girls with conduct problems. Eur Child Adolesc Psychiatry. doi:10.1007/s00787013-0416-8

18. Sonuga-Barke EJ (2011) Editorial: the elephant in the laboratoryon the influence of non-scientific assumptions on research in child psychology and psychiatry. J Child Psychol Psychiatry 52:1-2

19. van Andel HWH, Jansen LMC, Grietens H, Knorth EJ, van der Gaag RJ (2013) Salivary cortisol: a possible biomarker in evaluating stress and effects of interventions in young foster children? Eur Child Adolesc Psychiatry. doi:10.1007/s00787-013-0439-1 